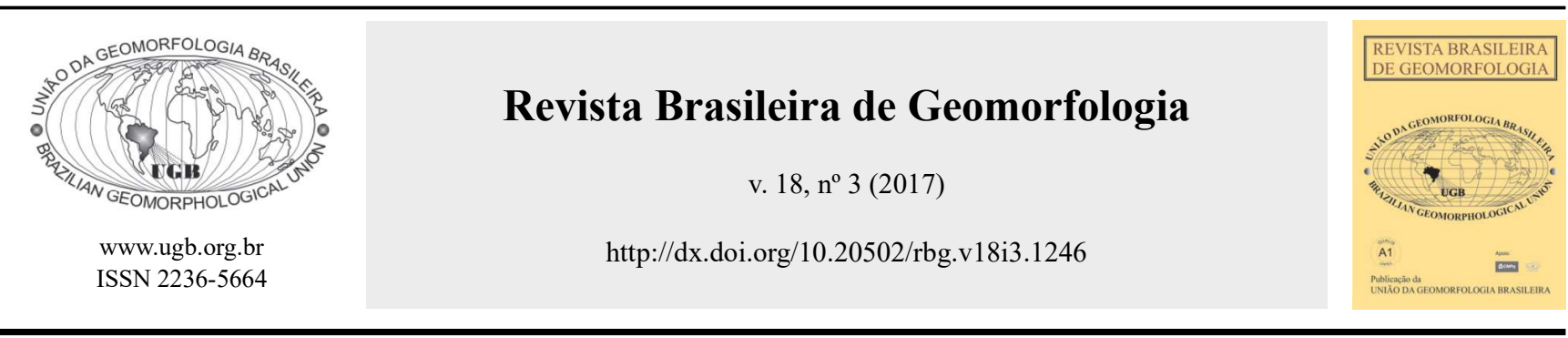

\title{
GEOMORPHOLOGY AND SEDIMENTOLOGY OF UNION GLACIER AREA, ELLSWORTH MOUNTAINS, OCCIDENTAL ANTARCTICA
}

\section{GEOMORFOLOGIA E SEDIMENTOLOGIA DA ÁREA DA GELEIRA UNION, MONTANHAS ELLSWORTH, ANTÁRTICA OCIDENTAL}

\author{
Vanessa do Couto Silva Costa \\ Instituto de Geociências, Universidade Federal Fluminense \\ Av. Gal. Milton Tavares de Souza, s/n, Niterói, Rio de Janeiro. CEP: 24210-346. Brasil \\ Email:vanessacosta@id.uff.br \\ Rosemary Vieira \\ Instituto de Geociências, Universidade Federal Fluminense \\ Av. Gal. Milton Tavares de Souza, s/n, Niterói, Rio de Janeiro. CEP: 24210-346. Brasil
}

Email: rosemaryvieira@id.uff.br

Jefferson Cardia Simões

Instituto de Geociências, Universidade Federal do Rio Grande do Sul Av. Bento Gonçalves, 9500, Porto Alegre, Rio Grande do Sul. CEP: 91501-970. Brasil

Email: jefferson.simoes@ufrgs.br

\section{Informações sobre o Artigo}

Recebido (Received):

27/03/2017

Aceito (Accepted):

$15 / 05 / 2017$

\section{Keywords:}

Moraines; Ellsworth

Mountains; Antarctica.

\section{Palavras-chave:}

Montanhas Ellsworth; Morainas; Antártica.

\begin{abstract}
:
The work aims to investigate the geomorphological and sedimentological

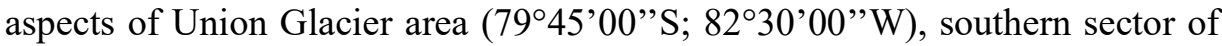
Ellsworth Mountains. Geomorphological cartography based on $15 \mathrm{~m}$ ASTER (2010) satellite imagery and field works were carried out during the Brazilian expedition (2011/2012) enabled the identification of morainic formations: icecored hummock moraines, supraglacial moraines, and recession moraines in the interior of the valleys. With the exception of the latter one, all types of moraines have been developed on the blue-ice areas. The evidence for paleo wet-based glacial conditions is reconstructed from a range of geomorphological record, including exposed abrasion marks, striations and glaciotectonic deformation. This type of deformation is represented by lee sides of oversteepening bedrock promontories which follow the tributaries of glaciers ice flow. Glacial sediments were collected from the moraines for granulometric and morphometric analyses. They show the prevalence of sandy gravel and sand texture, low quantity of fine fractions, and absence of attributes such as striated and faceted clasts, which indicate, on the other side, low-sediment transport capacity from the ice sheet bottom. It is inferred that the moraine debris are originated from local sources. Weathering action and constant katabatic winds are possibly the major agents of transport and alteration of the exposed sediments. The geomorphological features
\end{abstract}


reveal an ancient thicker ice sheet, and sedimentary characteristics of the morainic formations reveal a latter thinner ice sheet in this sector of Ellsworth Mountains.

\section{Resumo:}

O trabalho objetiva examinar as feições geomorfológicas e sedimentológicas de morainas na área da Geleira

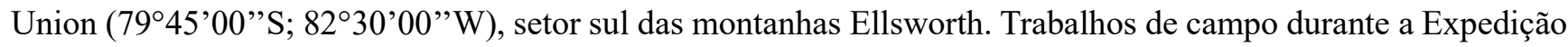
Criosfera no verão de 2011/2012 e cartografia com imagem ASTER (2010) possibilitaram identificar formações morâinicas: morainas com núcleo de gelo, morainas supraglaciais e morainas de recessão no interior de vales. Exceto pela última, as demais morainas se desenvolveram nas áreas de gelo-azul. Evidências de atividade de geleiras de condição termo-basal úmida são reconstruídas a partir de registros geomorfológicos, incluindo marcas de abrasão, estrias, feições stoss e lee que seguiam o fluxo de gelo das geleiras tributárias. Amostras de sedimentos glaciais foram coletadas das morainas e analisadas, revelando o predomínio de textura cascalho arenosa e arenosa, e baixa quantidade de material fino. A ausência de atributos, tais como clastos estriados e facetados indicam, por outro lado, pouca capacidade de transporte de sedimento desde a base do manto de gelo. Ações locais de intemperismo e ventos catabáticos constantes são possivelmente os principais agentes de transporte e alteração dos sedimentos expostos. As características geomorfológicas revelam um manto de gelo mais espesso e as caraterísticas sedimentares das morainas revelam um manto de gelo menos espesso nessa parte das Montanhas Ellsworth.

\section{Introduction}

Past fluctuations of the West Antarctic Ice Sheet (WAIS) are of fundamental concern for the possibility of WAIS collapse in the future and a consequent rise in global sea level (HEIN et al., 2016). The WAIS volume has undergone fluctuations since the Quaternary, from expansion events, with ice covering local mountains and valleys, to the retraction events with exposure of subglacial topography. Several years of research have produced a large set of geological data constraining Antarctic Ice Sheet history, based on the significant progress of acquisition methods and analysis of terrestrial and marine records of past ice-sheet thickness and extent (RAISED, 2014). Geomorphic/geologic studies can provide evidence of past behavior, e.g. the changes associated with a glacial cycle, which has implications for former basal regimes and the erosive potential of a glacial cycle (SUGDEN et al., 2006).

There is evidence for the sensitivity of the WAIS to the climate variations during the last glacial cycle, especially in its peripheral areas. Marine biology studies suggest the disappearance of great part of the ice sheet during interglacials, creating an open seaway between the Pacific and Atlantic sectors (SCHERER et al., 1998; BARNES and HILLENBRAND, 2010; STRUGNEL et $a l ., 2012)$. The ice sheet is shrinking in size since the Last Glacial Maximum (LGM) in all sectors, especially in the Pacific-facing sector (FOGWILL et al., 2011; JOUGHIN et al., 2014; RIGNOT et al., 2014). The ice sheet reduction in size and thickness has generated exposed areas with a variety of erosional and depositional forms.

Ellsworth Mountains are located near the modern grounding line zone between the WAIS and Ronne-Filchner Ice Shelf, and exhibit the former levels of past expansion and retreat printed on the landscape (DENTON et al., 1992). Outlet glaciers flow around the nunatacks and from the valleys toward the Filchner-Ronne Ice Shelf in Hercules Inlet (RIVERA et al., 2014).

Geomorphological evidences in the Ellsworth Mountains suggest that the WAIS was between 450 to $600 \mathrm{~m}$ higher during the LGM (ACKERT et al., 1999; FOGWILL et al., 2011). Bentley et al. (2010) show that during this period the ice cover was at least $430 \mathrm{~m}$ thicker, and that the WAIS in the Ellsworth Mountains region has decreased its thickness up to $480 \mathrm{~m}$ in the past $15 \mathrm{ky}$. Recent study of Hein et al. (2016) suggests the continuous presence of the ice sheet in the southern Ellsworth Mountains uplands for 1.4 Ma, while the sectors near de grounding line have experienced loss of marine-based portions during some interglacials throughout the Pleistocene. A more recent study with analysis of rock samples in the same area reveals that some clasts have been exposed on glacially mounded surfaces for at least $1.4 \mathrm{Ma}$ and perhaps more than $3.5 \mathrm{Ma}$ (SUGDEN et al., 2017).

The Ellsworth Mountains are an area of high concentration of surface deposits and erosional features, which contains records of the geological, climatic and environmental history. Fogwill et al. (2011) recorded blue-ice moraines on Soholt Peaks, Liberty Hills, Independence, Mar- 
ble and Patriot Hills (Heritage Range). Vieira and Simões (2011) and Vieira et al. (2012) identified and described, respectively, the glacial geomorphology of Independence and Patriot Hills, and the periglacial features at Patriot Hills, such as rock glacier-like landform, creeping debris-mantled and steep debris-mantled slopes. Nevertheless, the interpretation of many erosional e depositional forms is still a puzzle for the regional glacial history.

The purpose of this work is to investigate the geomorphological and sedimentary aspects through depositional and erosional features in Union Glacier area, southern part of the Ellsworth Mountains, and its morphogenetic environments.

\subsection{Regional setting}

The Ellsworth Mountains form a NNE-SSW trending mountain range approximately $415 \mathrm{~km}$ long, centered at about $79^{\circ} \mathrm{S} 84^{\circ} \mathrm{W}$ (Figure 1); they are divided into two geographically distinct ranges, the Sentinel Range to the north, and the Heritage Range to the south (DENTON et al., 1992). The mountains are located along the northern periphery of the crustal block of the Ellsworth-Whitmore Mountains, which represent part of a displaced terrain once situated along the paleo-Pacific margin of Gondwana, prior to supercontinent breakup (STOREY, 2005).

Union Glacier (UG) has a total area of $2561 \mathrm{~km}^{2}$ and length of $86 \mathrm{~km}$, from the ice divide with the Institute Ice Stream down to the grounding line of Constellation Inlet on the Ronne Ice Shelf(RIVERA et al., 2014). The glacier is fed by several glacial valleys, flowing from the interior cirques and accumulation basins between mountains ridges (DENTON et al., 1992) (Figure 1). Union Glacier is characterized by an extensive blue-ice area swept by katabatic winds from the ice sheet and a central moraine line (RIVERA et al., 2010). The maximum ice thickness is $1540 \mathrm{~m}$, with a maximum snow ice boundary layer at $120 \mathrm{~m}$. Ice flow velocity is $20 \mathrm{~m} / \mathrm{y}$ and shows stability (RIVERA et al., 2014).

In the available climatic series for the region, from 2008 to 2012 , the mean daily air temperature was -20.6 ${ }^{\circ} \mathrm{C}$, with an absolute minimum of $-42.7^{\circ} \mathrm{C}$ (August 2008) and an absolute maximum of $0.5^{\circ} \mathrm{C}$ (January 2010). Wind speed and direction, between 2008 and 2012, have a mean value of $16.3 \mathrm{knots}$ and a predominant direction from $224^{\circ}$. The maximum wind speed recorded on site was near 60 knots and the predominant wind speeds are higher than 25 knots (RIVERA et al., 2014 - Figure 1).
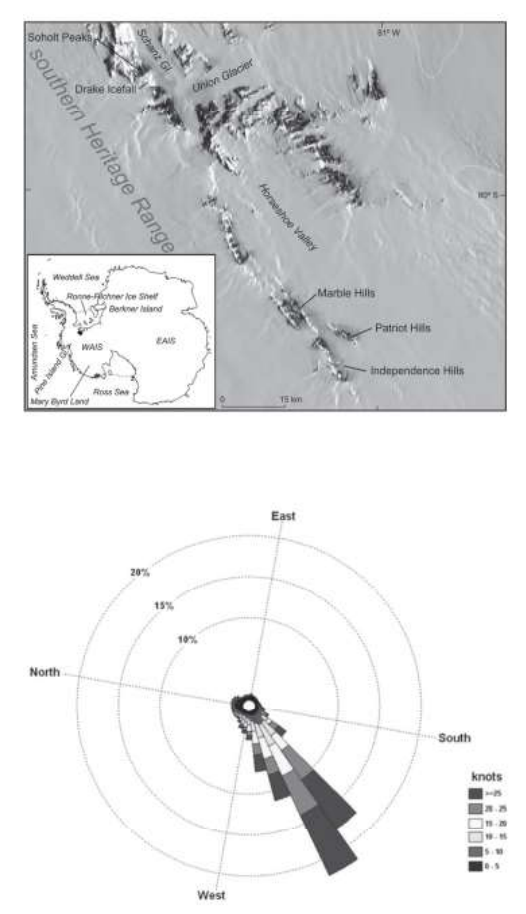

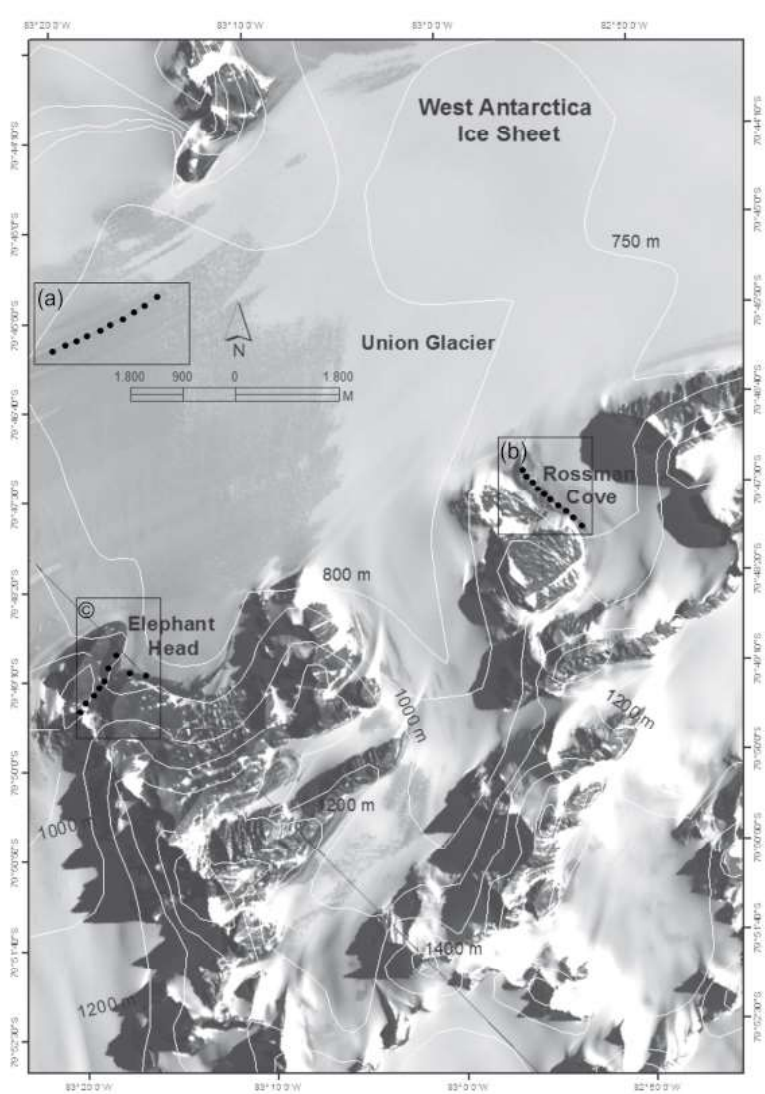

Figure 1 - Union glacier area (sources: ASTER, 2010; FOGWILL et al., 2011). Predominant wind speed and direction for 2008-2012 at the Union Glacier automatic weather station, installed near stake V17 (RIVERA et al., 2014). Sample sites shown in rectangles sets and in black circles: (a) Union glacier; (2) Rossman Cove; (c) Elephant Head. 


\section{Methods}

Identification and classification of moraines as well as observations and measurements of glacial erosional and depositional features, in particular, were performed in 2011-2012 summer season, during the Brazilian Cryosphere Expedition.

Sediments were sampled at: (a) Union Glacier (11 samples); (b) Rossman Cove (10 samples); (c) Elephant Head (9 samples) (Figure 1 and Table 1). $100 \mathrm{~g}$ of superficial sediments were collected with a spoon in shallow cavities in order to avoid weathered material, and identified with codes. At each sampling site, control points (GPS coordinates and altitude), photography and observation of the surrounding environment were obtained. For morphometric analysis, 50 clasts were collected with major axis $>15 \mathrm{~mm}$ from each sample site.

The particle size was determined in the laboratory by dry sieving at phi intervals of $-3 \phi$ to $4 \phi(8 \mathrm{~mm}$ to 0,63 $\mathrm{mm})$. Descriptive statistics for particle-size-distribution were obtained using Gradistat, including mean, percentage distributions of gravel, sand and mud and sorting for logarithmic distributions (e.g. FOLK and WARD, 1957). Morphometric analysis of clasts was carried out on 50 clasts with major axis $>15 \mathrm{~mm}$ in the digital caliper to visually determine the relative size of the three orthogonal axes: $a$ (longest), $b$ (intermediate) and $c$ (shortest).

Roundness (clast size from 2 to $8 \mathrm{~mm}$ ) was obtained with the aid of a binocular microscope using the descriptive criteria provided by Benn and Ballantine (1994). The estimated roundness classes for each sample was translated into percentages and plotted as frequency distributions. The percentages of very angular (VA) and angular (A) were added to calculate the RA-index. Additionally, shape and roundness were summarized using $\mathrm{C}_{40}$ index ( $\%$ of clasts which axis $\left.c / a \leq 0.4\right)$. RA-index ( $\%$ of angular and very angular clasts) and RWR-index ( $\%$ of rounded and well-rounded clasts) were conducted according the method proposed by Benn and Balllantyne (1994), Evans and Benn (2004), and LUKAS et al. (2013) in order to distinguish between erosional, transportational and depositional clast histories. We plotted both RA/ RWR and $\mathrm{C}_{40}$-index in covariant diagrams to allow a clear distinction between sediments predominantly being passively supraglacially transported and those which have been actively subglacially transported (BENN and BALLANTYNE, 1994; BENNETT et al., 1997; LUKAS et al., 2013). Ternary diagrams (using Triplot) and histo- grams display clast shape and roundness.

The mapping of geomorphological and glaciological features was based on GPS control-points and ASTER imagery (Advanced Spaceborne Thermal Emission Reflection Radiometer) data. The scenes were acquired on 27/01/2010 with spatial resolution of $15 \mathrm{~m}$ data. Morphological features identified in ASTER visible/ near-infrared (VNIR) color composite scenes (RGB 321) and verified during field activities were recorded using a portable GPS, with an error of about $3 \mathrm{~m}$. The newly detected morphological features were mapped using ArcGis $\bigcirc$ software. Geomorphological mapping was elaborated with Polar Stereographic coordinate and WGS84 geodetic reference system.

\section{Results and Discussion}

\subsubsection{Geomorphological features}

Figure 2 represents a geomorphological and glaciological map. Well-preserved glacial and periglacial landforms could be identified based on visual interpretation of ASTER images and in field activities, including moraines and micro-scale/meso-scale erosional features (striation and stoss and lee-Figs. 3a-b). Three morainic assemblages were identified: ice-cored hummock moraines, supraglacial moraines, and recession moraines in the interior of the valleys.

Two major erosional features were identified on exposed outcrops at the northeast Rossman Cove Hills side, situated at 40-50 meters above ice surface. Well-defined and preserved potholes, grooves and striations reveal abrasion by glaciers at different periods (Figure 3a-b). Some of them present visible signs of oxidation, with reddish-brown color. These striations are typical of glacial abrasion beneath warm-based ice (SUGDEN et al., 2017). Brightened colored striation can be produced by more recent glacial activity since they were not affected by oxidation.

A stoss and lee feature carved from bedrock (Figure $3 \mathrm{c}$ ) is the most obvious evidence for the erosive action of overriding ice on the local topography, with smoothly stoss face abraded up ice and plucked down-ice lee face. The top-surface of this outcrop displays extensive subaerial weathering, and no till veneers were found. This landform indicates a past thickest ice sheet covering part of the topography, since the summit of the hill is approximately 200 meters above current ice surface. The feature also indicates an ancient glacier flow toward to UG (Figure 2). 
Geomorphology and Sedimentology of Union Glacier Area, Ellsworth Mountains, Occidental Antarctica

Table 1: Latitude, longitude, and sampling information for Union Glacier, Rossman Cove and Elephant Head samples.

\begin{tabular}{|c|c|c|c|c|c|c|}
\hline Sample ID & Latitude & Longitude & $\begin{array}{l}\text { Altitude } \\
\text { (m.a.s.l) }\end{array}$ & Silt (\%) & Sand (\%) & Gravel (\%) \\
\hline \multicolumn{7}{|l|}{ Union Glacier } \\
\hline UG-MO-01 & $79^{\circ} 45^{\prime} 51.8^{\prime \prime} \mathrm{S}$ & $83^{\circ} 14^{\prime} 55.0^{\prime \prime} \mathrm{W}$ & 762 & 0,8 & 14,1 & 85,2 \\
\hline UG-MO-02 & $79^{\circ} 45^{\prime} 59.1$ 'S & $83^{\circ} 15^{\prime} 09.2^{\prime \prime} \mathrm{W}$ & 756 & 0,1 & 16,9 & 83,0 \\
\hline UG-MO-03 & $79^{\circ} 45^{\prime} 66.6$ ” S & $83^{\circ} 15^{\prime} 89.5^{\prime \prime} \mathrm{W}$ & 759 & 0,1 & 31,9 & 68,0 \\
\hline UG-MO-04 & $79^{\circ} 45^{\prime} 73.7^{\prime} \mathrm{S}$ & $83^{\circ} 16^{\prime} 68.0^{\prime \prime} \mathrm{W}$ & 767 & 0 & 10,9 & 89,1 \\
\hline UG-MO-05 & $79^{\circ} 45^{\prime} 81.0 ” \mathrm{~S}$ & $83^{\circ} 17^{\prime} 58.5^{\prime \prime} \mathrm{W}$ & 767 & 2,4 & 10,4 & 87,2 \\
\hline UG-MO-06 & $79^{\circ} 45^{\prime} 86.1$ ”S & $83^{\circ} 18^{\prime} 22.0^{\prime \prime} \mathrm{W}$ & 762 & 0,1 & 23,7 & 76,3 \\
\hline UG-MO-07 & $79^{\circ} 45^{\prime} 91.7$ 'S & $83^{\circ} 18^{\prime} 98.9^{\prime \prime} \mathrm{W}$ & 753 & 3,1 & 4,1 & 92,9 \\
\hline UG-MO-08 & $79^{\circ} 45^{\prime} 97.5^{\prime \prime} \mathrm{S}$ & $\begin{array}{c}83^{\circ} 19^{\prime} \\
81.8^{\prime \prime} \mathrm{W} \\
\end{array}$ & 766 & 0 & 13,5 & 86,5 \\
\hline UG-MO-09 & $79^{\circ} 46^{\prime} 03.5 ” \mathrm{~S}$ & $83^{\circ} 20^{\prime} 72.8^{\prime \prime} \mathrm{W}$ & 772 & 2,8 & 21,5 & 75,7 \\
\hline UG-MO-010 & $79^{\circ} 46^{\prime} 08.8^{\prime \prime S}$ & $83^{\circ} 21^{\prime} 57.2^{\prime \prime} \mathrm{W}$ & 776 & 0 & 12,8 & 87,1 \\
\hline \multicolumn{7}{|l|}{ Rossman Cove } \\
\hline Beach-MO-01 & $79^{\circ} 47^{\prime} 89.2^{\prime \prime S}$ & $82^{\circ} 53^{\prime} 36.9^{\prime \prime} \mathrm{W}$ & 747 & 0 & 24,2 & 75,8 \\
\hline Beach-MO-02 & $79^{\circ} 47^{\prime} 84.9^{\prime \prime} \mathrm{S}$ & $82^{\circ} 53^{\prime} 53.6^{\prime \prime} \mathrm{W}$ & 763 & 0 & 27,6 & 72,4 \\
\hline Beach-MO-03 & $79^{\circ} 47^{\prime} 80.8$ "S & $82^{\circ} 53^{\prime} 74.7^{\prime \prime} \mathrm{W}$ & 766 & 0,1 & 18,7 & 81,2 \\
\hline Beach-MO-04 & $79^{\circ} 47^{\prime} 75.7^{\prime \prime} \mathrm{S}$ & $82^{\circ} 54^{\prime} 01.1$ ' W & 761 & 0,1 & 23,0 & 76,9 \\
\hline Beach-MO-05 & $79^{\circ} 47^{\prime} 71.7 ” \mathrm{~S}$ & $82^{\circ} 54^{\prime} 29.2^{\prime \prime} \mathrm{W}$ & 766 & 0,4 & 26,3 & 73,3 \\
\hline Beach-MO-06 & $79^{\circ} 47^{\prime} 68.6 ” \mathrm{~S}$ & $82^{\circ} 54^{\prime} 58.4^{\prime \prime} \mathrm{W}$ & 752 & 0,1 & 18,5 & 81,4 \\
\hline Beach-MO-07 & $79^{\circ} 47^{\prime} 60.9^{\prime \prime S}$ & $82^{\circ} 54^{\prime} 85.0^{\prime \prime} \mathrm{W}$ & 741 & 0,1 & 14,9 & 85,0 \\
\hline Beach-MO-08 & $79^{\circ} 47^{\prime} 56.2 ” \mathrm{~S}$ & $82^{\circ} 55^{\prime} 09.6^{\prime \prime} \mathrm{W}$ & 738 & 0,3 & 24,1 & 75,7 \\
\hline Beach-MO-09 & $79^{\circ} 47^{\prime} 50.3$ "S & $82^{\circ} 55^{\prime} 39.7^{\prime \prime} \mathrm{W}$ & 738 & 0 & 11,6 & 88,3 \\
\hline Beach-MO-10 & $79^{\circ} 47^{\prime} 43.9^{\prime \prime} \mathrm{S}$ & $82^{\circ} 55^{\prime} 71.1^{\prime \prime} \mathrm{W}$ & 726 & 0,1 & 19,7 & 80,2 \\
\hline \multicolumn{7}{|l|}{ Elephant Head } \\
\hline EHV-01 & $79^{\circ} 49^{\prime} 29.8^{\prime \prime S} \mathrm{~S}$ & $83^{\circ} 20^{\prime} 42.6^{\prime \prime} \mathrm{W}$ & 810 & 0,1 & 39,6 & 60,3 \\
\hline EHV-02 & $79^{\circ} 49^{\prime} 23.8^{\prime \prime S} \mathrm{~S}$ & $83^{\circ} 18^{\prime} 92.8^{\prime \prime} \mathrm{W}$ & 739 & 0,1 & 52,5 & 47,4 \\
\hline EHV-03 & $79^{\circ} 49^{\prime} 13.1 " \mathrm{~S}$ & $83^{\circ} 18^{\prime} 42.5^{\prime \prime} \mathrm{W}$ & 691 & 0,0 & 41,8 & 58,2 \\
\hline EHV-04 & $79^{\circ} 49^{\prime} 28.9^{\prime \prime S}$ & $83^{\circ} 20^{\prime} 02.0^{\prime \prime} \mathrm{W}$ & 818 & 0,4 & 29,5 & 70,1 \\
\hline EHV-05 & $79^{\circ} 49^{\prime} 22.9^{\prime \prime S}$ & $83^{\circ} 19^{\prime} 07.7^{\prime \prime} \mathrm{W}$ & 741 & 0,1 & 48,9 & 51,0 \\
\hline EHV-06 & $79^{\circ} 49^{\prime} 03.2$ "S & $83^{\circ} 18^{\prime} 03.2^{\prime \prime} \mathrm{W}$ & 700 & 0,2 & 38,6 & 61,2 \\
\hline EH-MO-01 & $79^{\circ} 49^{\prime} 11.1 " \mathrm{~S}$ & $83^{\circ} 16^{\prime} 10.7^{\prime \prime} \mathrm{W}$ & 718 & 0,5 & 10,9 & 88,6 \\
\hline EH-MO-02 & $79^{\circ} 49^{\prime} 01.2 ” \mathrm{~S}$ & $83^{\circ} 12^{\prime} 25.4^{\prime \prime} \mathrm{W}$ & 737 & 0,2 & 13,0 & 86,9 \\
\hline EH-MO-03 & $79^{\circ} 49^{\prime} 05.4^{\prime \prime S}$ & $83^{\circ} 12^{\prime} 39.6^{\prime \prime} \mathrm{W}$ & 782 & 0,5 & 14,0 & 85,5 \\
\hline
\end{tabular}


Costa V. C. S. et al.

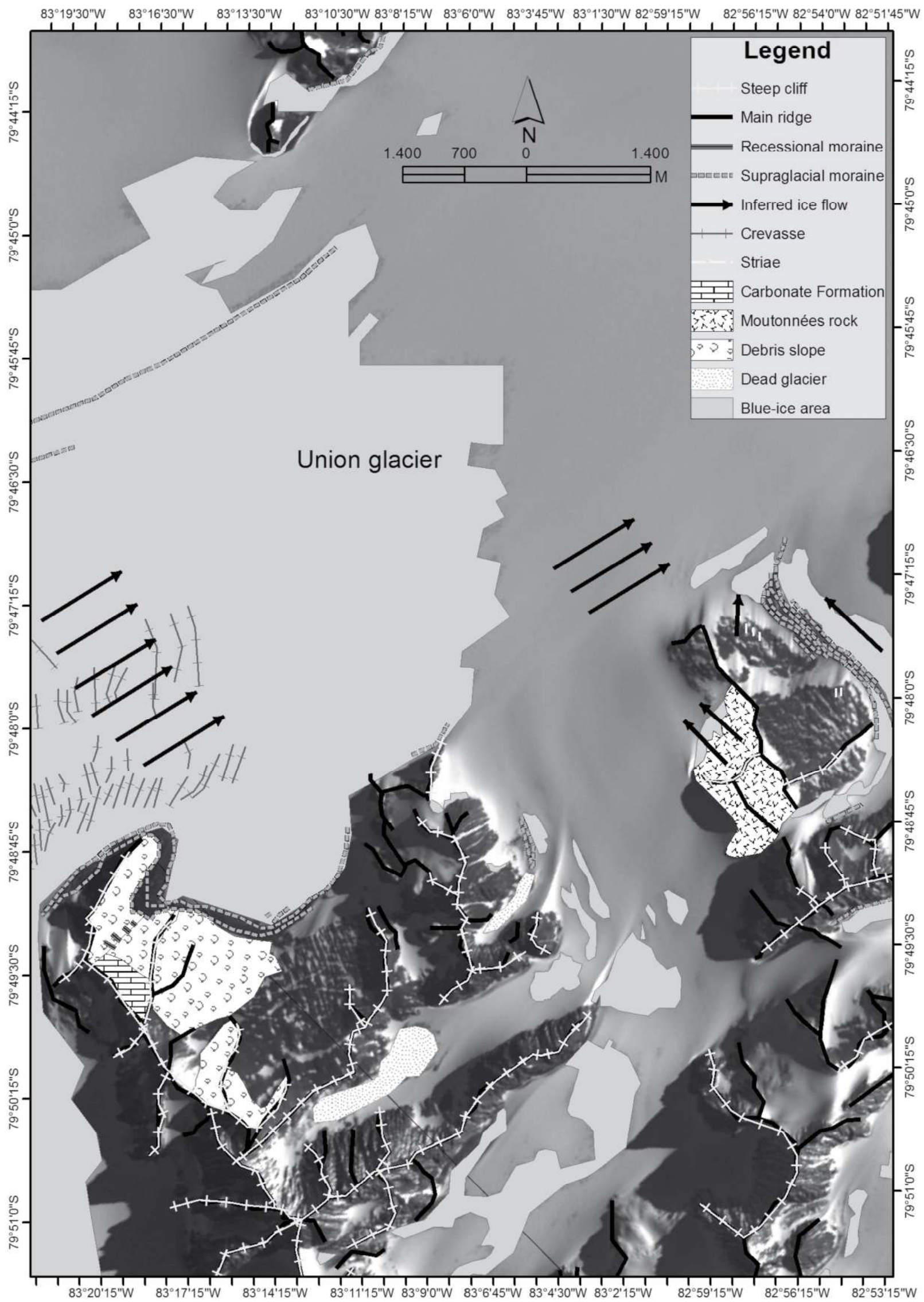

Figure 2 - Geomorphological and glaciological map (with background image Aster color composite 321 acquired on 27/01/2010). Glacier flow is inferred by the geomorphological features and Rivera et al. (2014). 

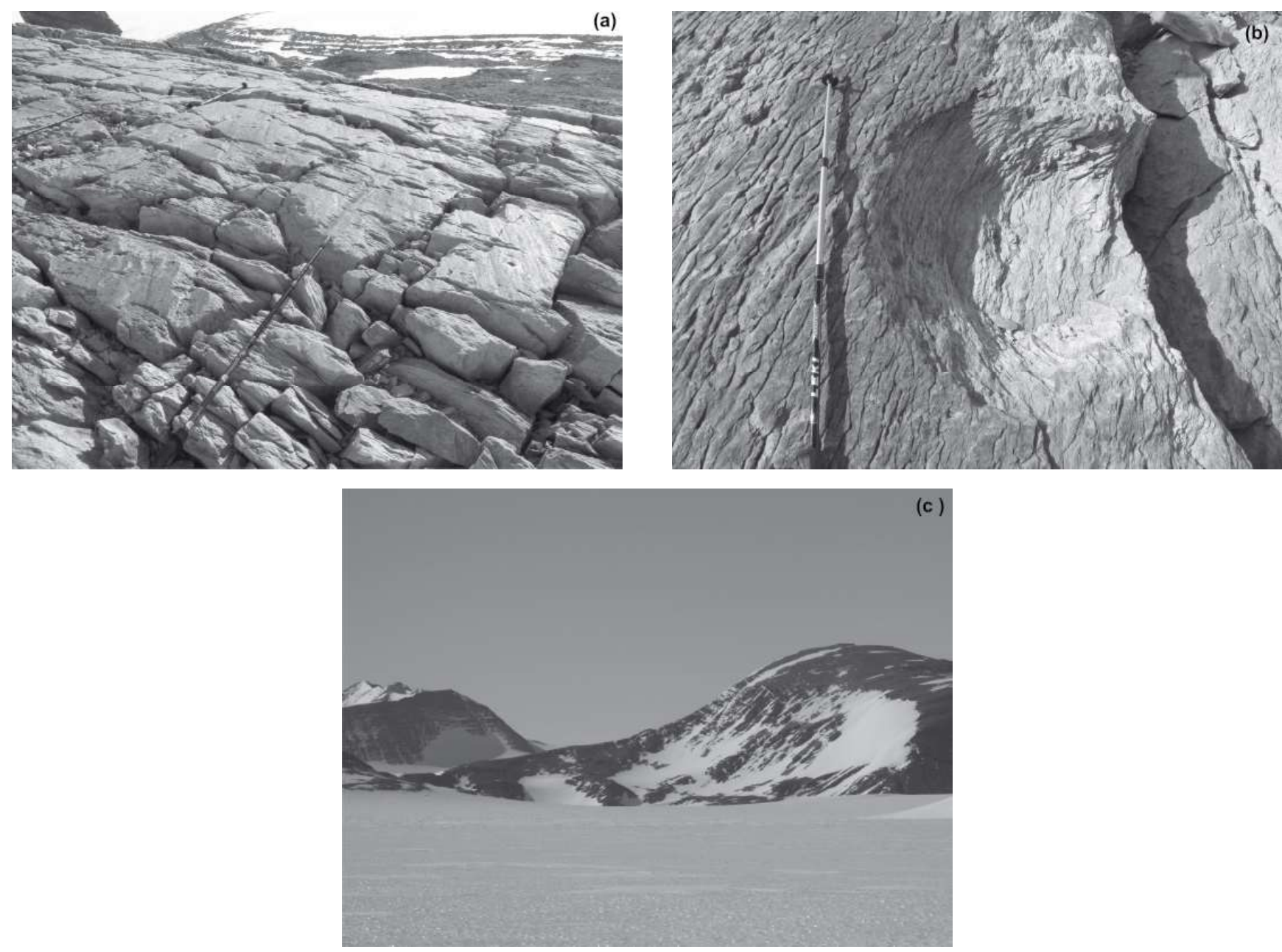

Figure 3 - (a) Striations on Rossman Cove bedrocks; (b) potholes on Rossman Cove bedrocks; (c) Stoss and lee feature in Rossman Cove area. The summit of the hill is approximately 200 meters above current ice surface.

Depositional features were fairly found in Rossman Cove, Elephant Head Valley and Union Glacier, and are represented by supraglacial/ice-cored moraine. Ice-cored hummocky moraines were observed at the margin of UG, at Mount Dolence. With the exception of Elephant Head Valley, all investigated moraines have developed on the blue-ice areas, and massive ice was recorded below the debris cover.

Ice-cored moraines emerge on the current ice-sheet at the northeast side of Rossman Cove, central part of UG and at Elephant Head Valley, at southern margin of UG. In Rossman Cove, the arcuate moraines are characterized by continuous ridges with narrow bands of debris-rich ice extending more than $2 \mathrm{~km}$ northeastward as a tail, indicating flow structures. The ridges are mainly 1-6 m of amplitude (Figs. 2 and 4).

Extensive high ice-cored moraine develops at the marginal flank of UG, against the Elephant Head Val- ley side, and fore wall of the Mount Dolence bedrock ridges, on the blue-ice ablation zone (Figure 5a). The moraine is high, over $7 \mathrm{~m}$, with a predominance of gravel and boulders. The ice-cored moraine becomes thicker toward the interior of the Elephant Head valley, which could be evidence for glacial flow toward this margin, periglacial processes with slope activities, or a past thick ice sheet (Figure $5 \mathrm{~b}$ ).

A long and narrow moraine of approximately 2.35 $\mathrm{km}$ develops in the center of UG, but the height does not exceed $1 \mathrm{~m}$ (Figure 6). The sediment is a mix of grain sizes, ranging from sand and gravel to boulders. The genesis of these moraines implicates different processes, but their location on the blue-ice area submits them to the inherent environmental conditions, such as the sublimation and erosion processes produced by the constant action of katabatic winds from the polar plateau, and, in addition, the complex spatial and temporal patterns of ice flow. 
Costa V. C. S. et al.

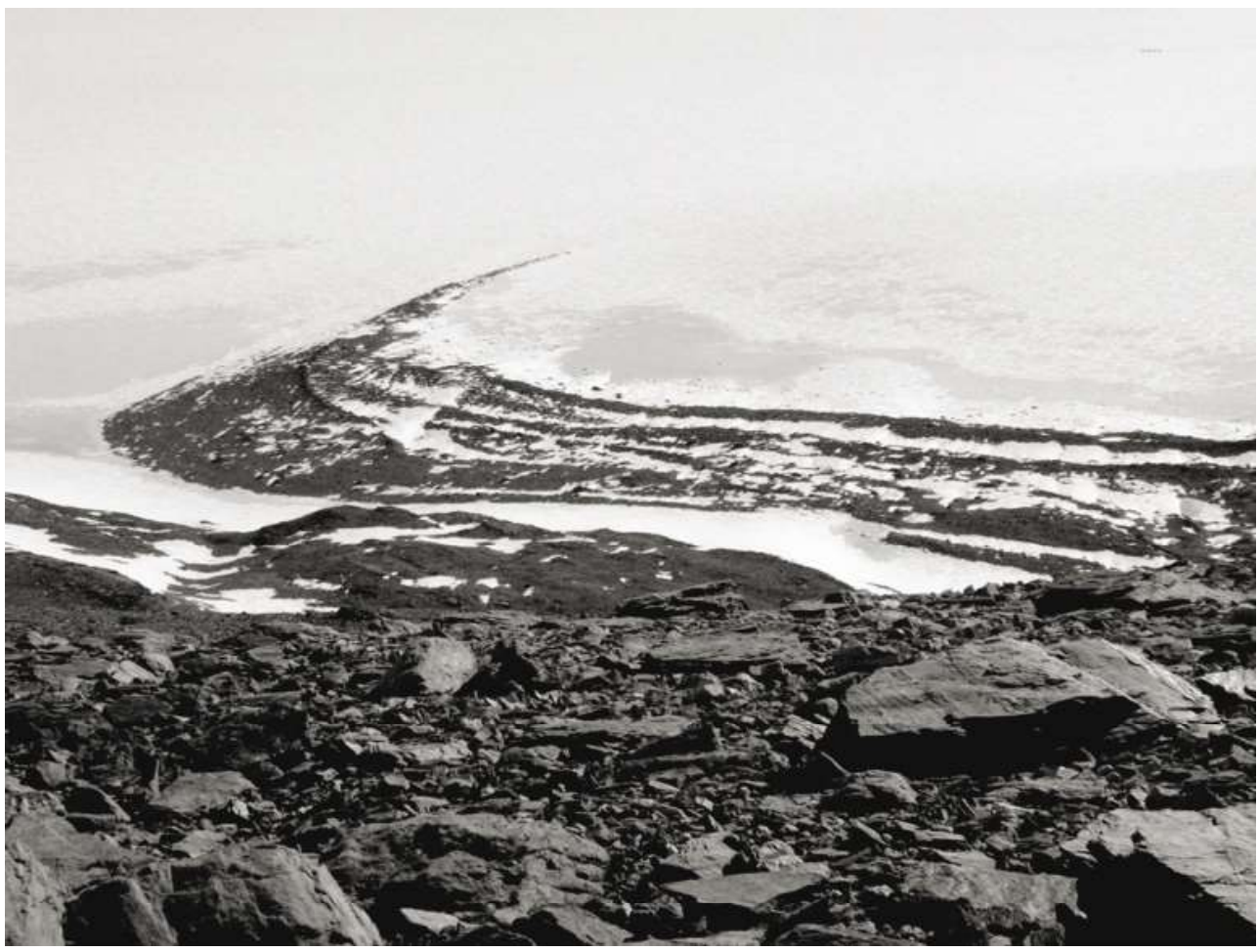

Figure 4 - Rossman Cove supraglacial moraine, with length of $2 \mathrm{~km}$, approximately.

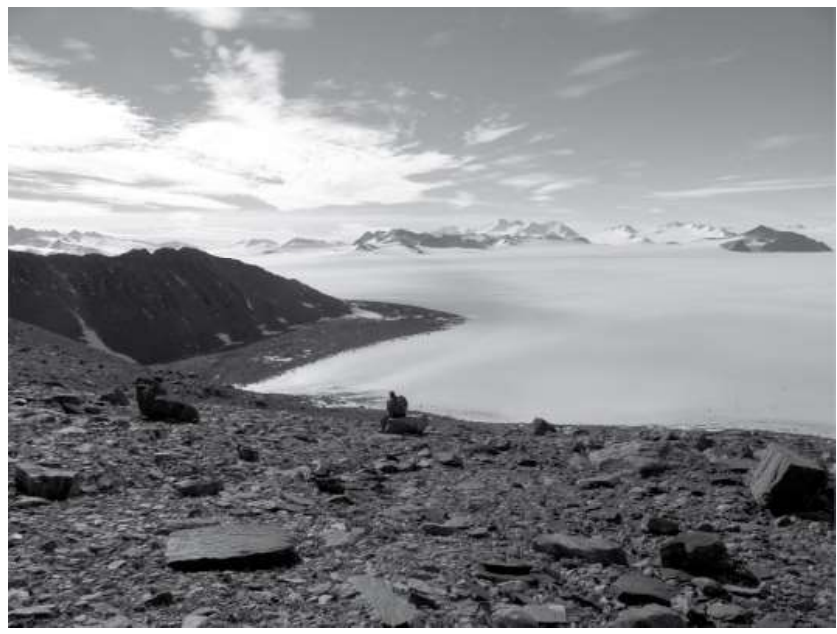

(a)

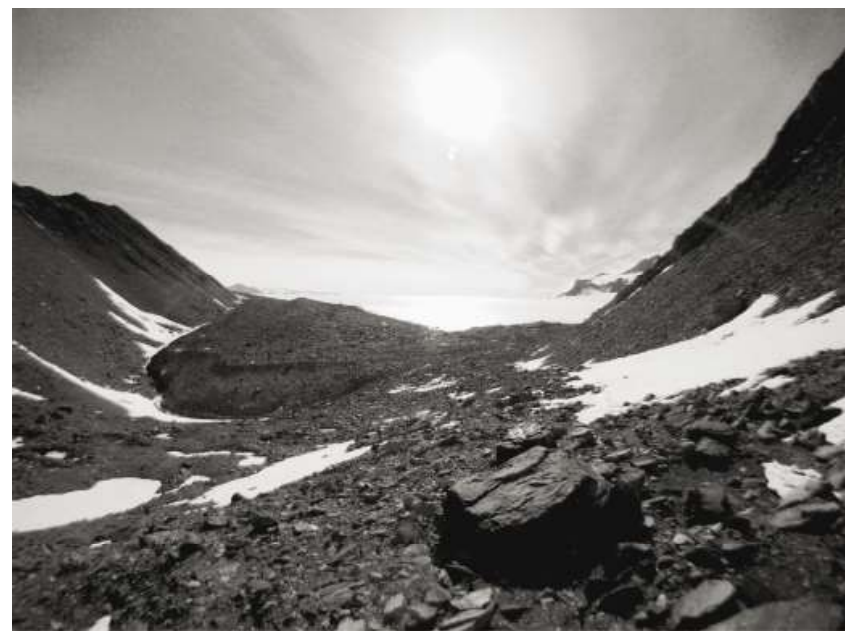

(b)

Figure 5 - (a) Elephant Head supraglacial moraine and blue-ice area, view from mount Dolence area; (b) Elephant Head supraglacial moraine and blue-ice area, view from the interior of the valley. 


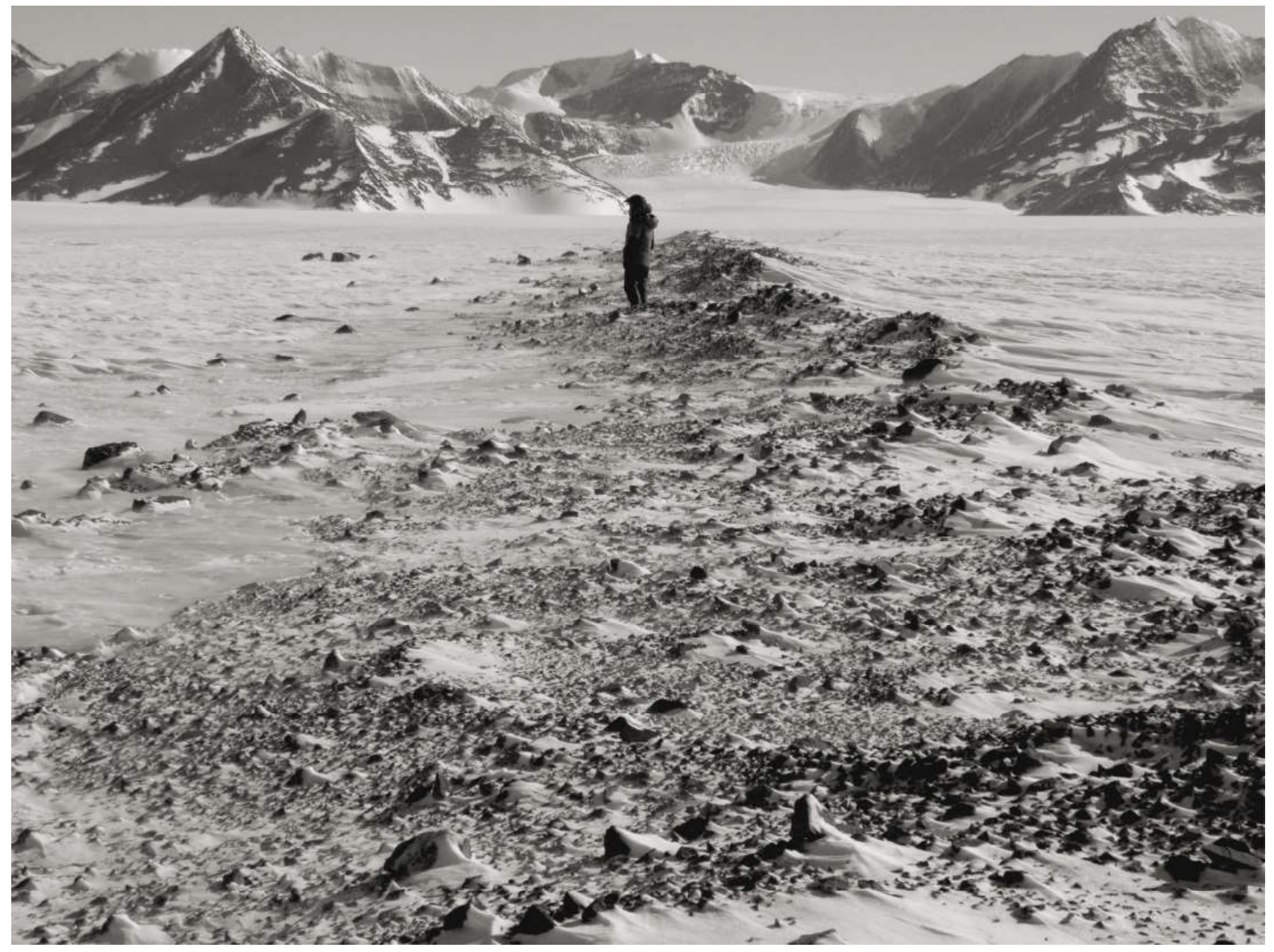

Figure 6 - Union Glacier moraine. Hyde glacier in the back.

\subsection{Sedimentological aspects: grain-size and clast shape analyses}

Sediment sampling at Union Glacier and Rossman Cove was carried out during occasional melting events, when subsurface material could be accessed. In UG samples particle size distribution presents small variations, but still distinct. The grain size analysis shows that the sediment consists of more than $68 \%$ gravel to sand (Table 1). Sand comprises $4-31 \%$ of the sediments. The content of silt and finer material does not exceed $3.1 \%$ and the average was only $1 \%$. As the region is subjected to strong winds, the concentration of gravel predominates on the surface. Therefore, the results indicate well-sorted sediments, and only two of them are poorly sorted. The histograms show the low proportion of very angular and angular clasts; clasts are predominantly sub-angular and sub-rounded (Figure 7). No striated or faceted clasts were observed.

The texture of the samples of Rossman Cove su- praglacial moraines is composed by at least $72 \%$ gravel and $21-27 \%$ sand (Table 1). Samples are divided into sandy gravel and sandy fine gravel. The content of silt and finer material does not exceed $0.4 \%$ and the average was only $0.1 \%$. The region is also subject to the action of strong winds, so the concentration of gravel also predominates on the surface. The samples are moderately to well-sorted, with the exception of Sample 5 . Modifications by wind abrasion and transport of finer particle size material may explain the higher percentage of rounded clasts on the surface (Figure 8).

Particle size analysis of recessional and supraglacial moraine at Elephant Head Valley shows the predominance of sandy gravel and sand textures (Table 1). The sand content ranges from 11 to $52 \%$, the highest sand content of all sampled sites. The valley is partially wind-protected and there is considerable debris supply from slopes, which may explain the increased presence of sands and poor selection of sediments. 

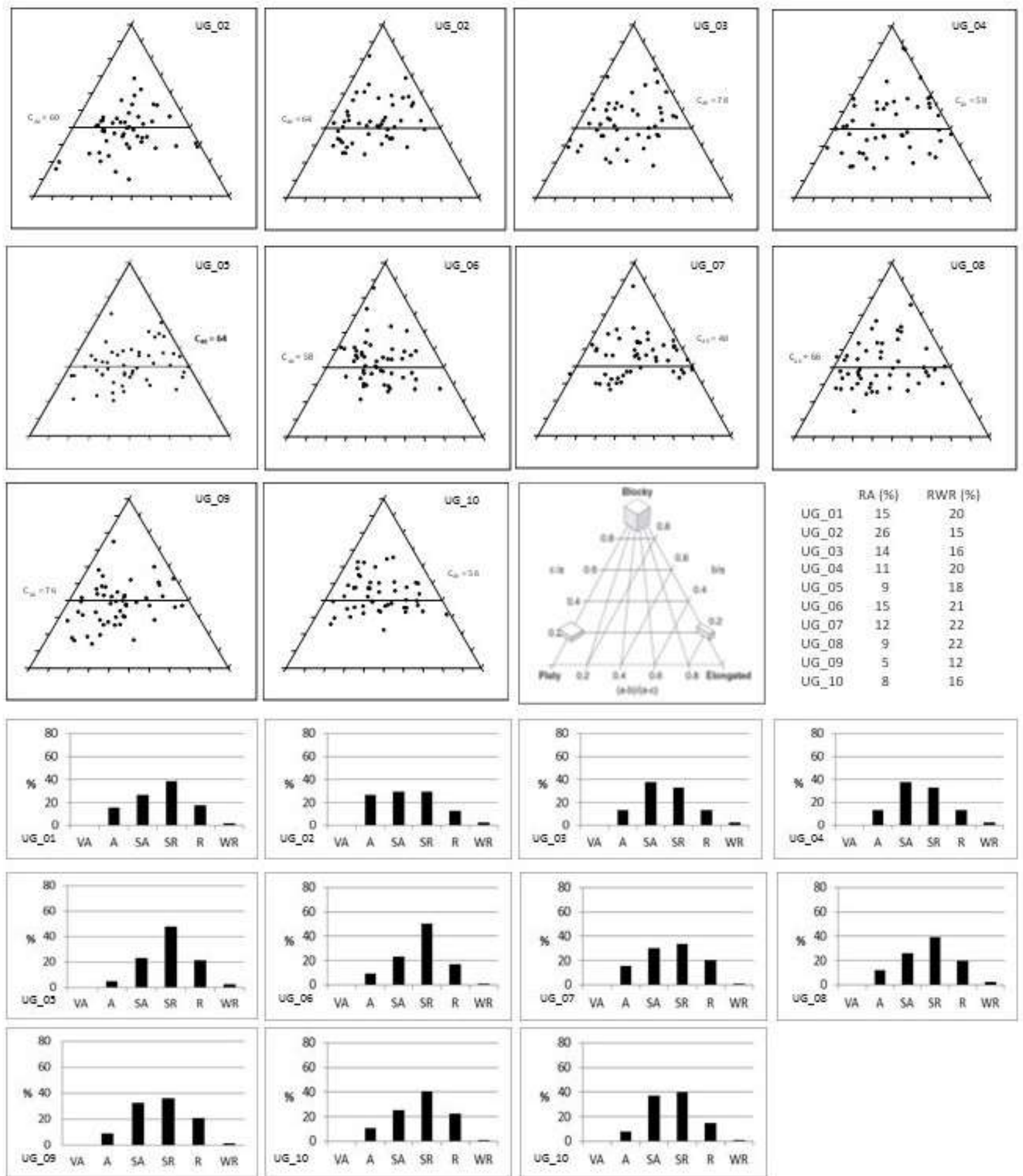

Figure 7 - Union Glacier: (a) ternary diagrams (form); (b) roundness histograms. RA (\% angular and very angular clasts); RWR (\% rounded and well-rounded clasts).

The supraglacial moraine is located at the margin of UG, next to the blue-ice area, with continuous local wind action, and it was the site with collected smaller number of samples, due to the high concentration of boulders and massive subsurface ice. The moraine rises between 5 and 8 meters above the present ice surface.
The percentage of samples of sandy gravel is greater than $85 \%$, followed by sands ( 10 to $14 \%$ ). Fine material is unexpressive. The prevalence of sub-angular and sub-rounded clasts may reveal that the action of wind in this area is intense (Figure 9). 

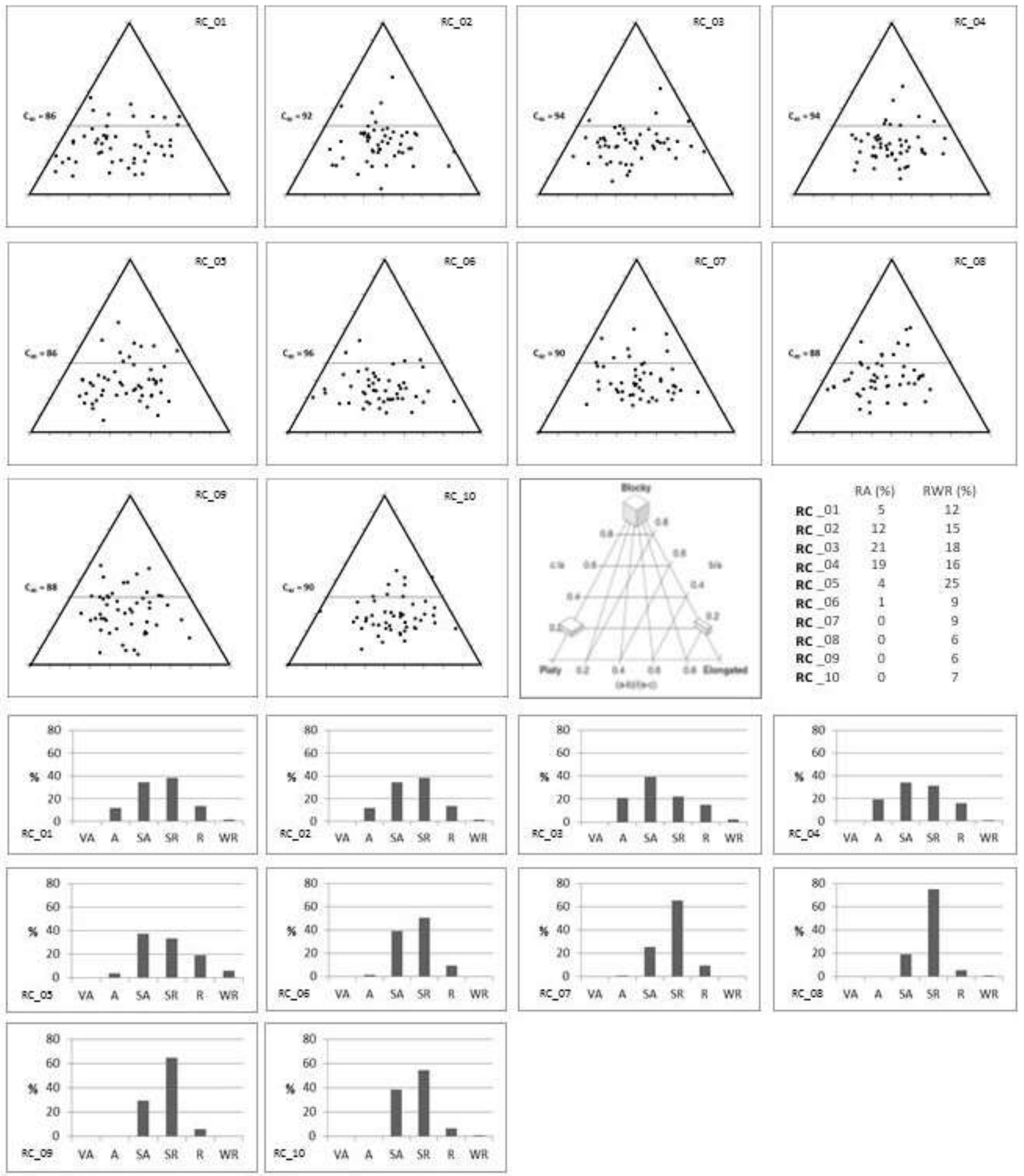

Figure 8 - Rossman Cove: (a) ternary diagrams (form); (b) roundness histograms. RA (\% angular and very angular clasts); RWR (\% rounded and well-rounded clasts).

Therefore, we interpret the supraglacial debris in this sector as originating mainly from surrounding slopes, which have supraglacially entrained, transported and accumulated in this area, as also observed in Dron- ning Maund Land (HÄTTESTRAND and JOHANSE, 2005) and in Marie Byrd Land (SUGDEN et al., 2005).

All the samples $(\geq 15 \mathrm{~mm})$ show a predominance of high $\mathrm{C}_{40}$ index that indicates discs and slabs shapes. 
The diagrams in Figure 10 show the covariant plot and analyses how two aspects of the clasts (shape and roundness) may vary with the origin and history of the transportation of glacial deposits (EVANS and BENN, 2004). The most sampled sites data showed little consistency, therefore not revealing the effective action of glacial transport on sediments form, which means short distance of transportation by the glacier or lack of meltwater subglacial activity. In this sense, it may be inferred that debris have been accumulated on the ice sheet surface rather than being transported away by the glacier. The morainic deposits, with the exception of sub-rounded clasts, have no significant signs of subglacial meltwater transport, such as fines and striated clast (HÄTTESTRANS and JOHANSEN, 2005; SUGDEN et al., 2005). In addition, there is no actual evidence for basally derived material brought to the surface by upward flow as observed in Patriot and Independence Hills (VIEIRA and SIMÕES, 2011; FOGWILL et al., 2011; HEIN et al., 2016). Finally, initial mineralogical analyses reveal local lithology as sediment provenance.
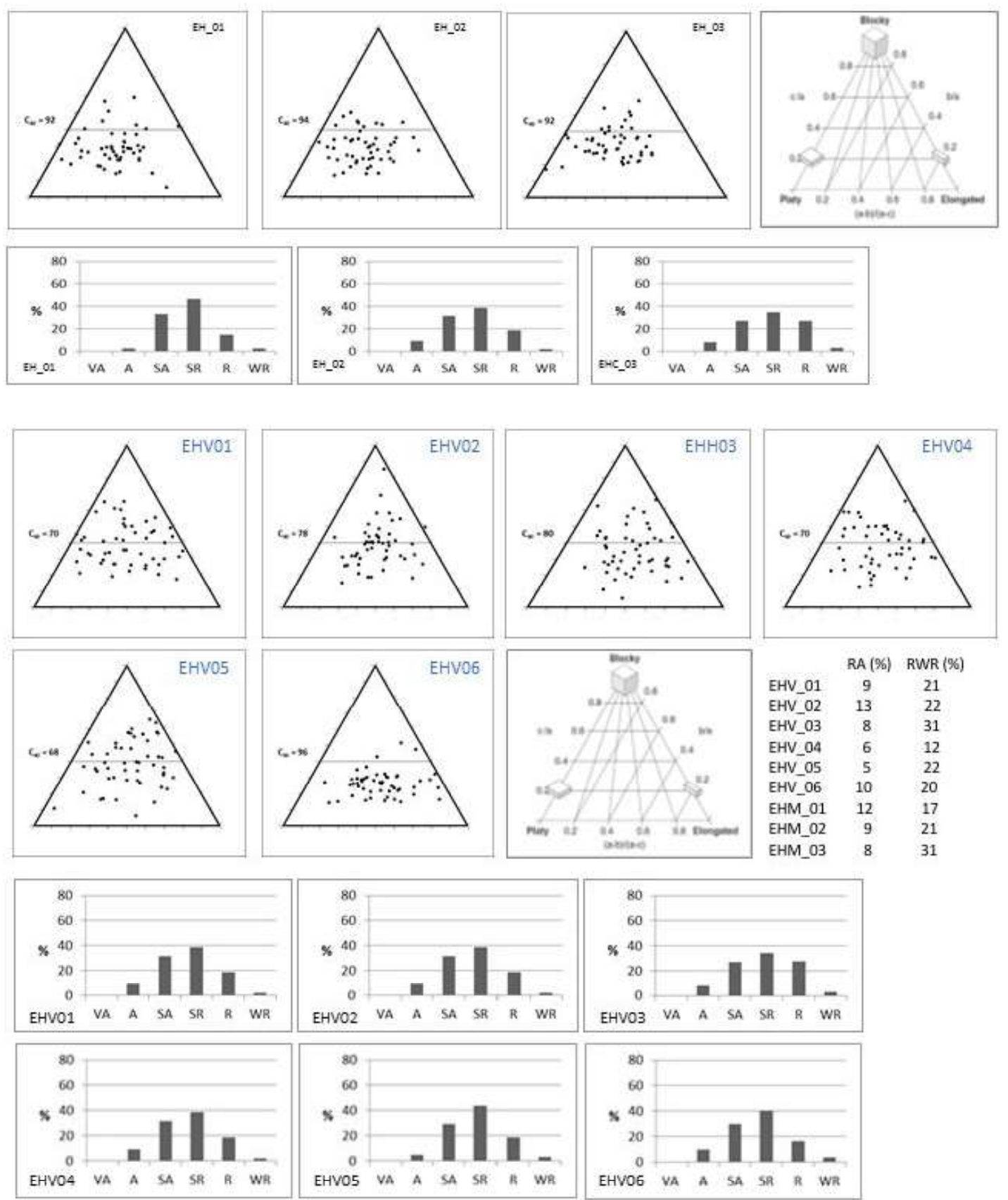

Figure 9 - Elephant Head: (a) ternary diagrams (form); (b) roundness histograms. RA (\% angular and very angular clasts); RWR (\% rounded and well-rounded clasts). 

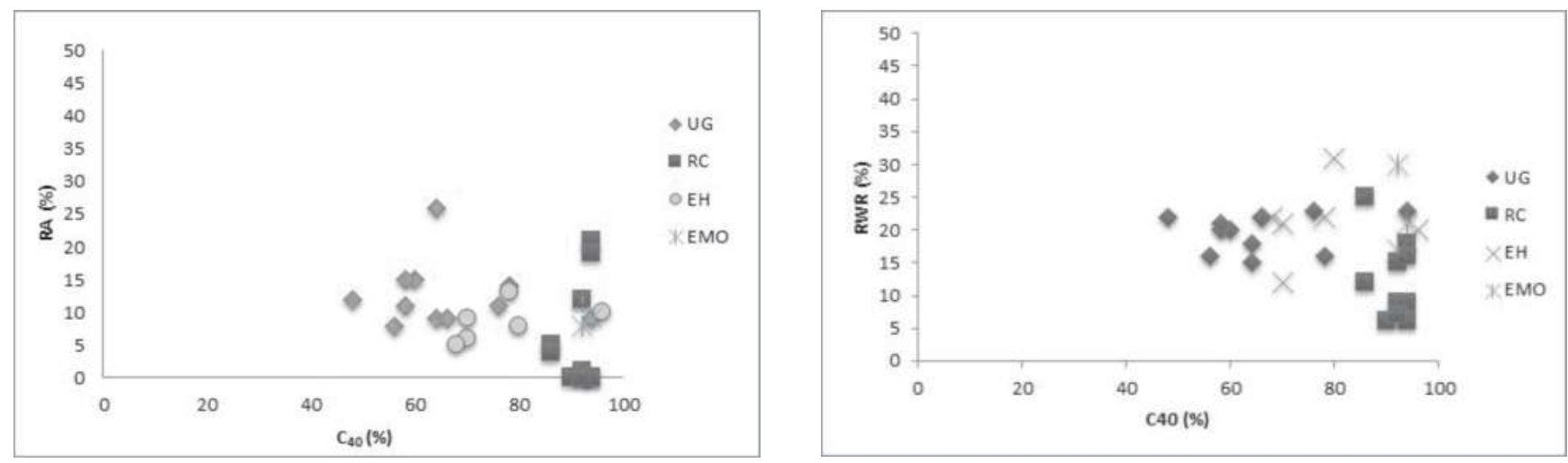

Figure 10 - Covariant plots of sediment samples: C40 (\% of clasts which axis c / a $\leq 0.4), R A$ (\% of angular and very angular clasts) and $R W R$ (\% rounded and well-rounded clasts). Each symbol represents one sample with 50 clasts: UG (Union Glacier); RC (Rossman Cove); EH (Elephant Head); EMO (Elephant Head Supraglacial Moraine).

Evidence for erosive action is clearly exposed in Rossman Cove area, with a $200 \mathrm{~m}$ high leeside escarpment, glacial striations and potholes on convex surfaces at the east side of the hill, more than $50 \mathrm{~m}$ above the present ice surface (Figs. 2 and 3a-3c). The thicker ice sheet and, consequently warm-based ice, may be the agent of these processes. Nonetheless, Atkins et al. (2002) and Hambrey and Fitzsimons (2010) show that cold-based glaciers, whose bed temperature is below the melting point, may cause considerable geomorphological action, not only the erosion of rocks but also the deposition of sediment, supplanting the conventional assumption that basal processes are ineffective in cold glaciers, therefore incapable of basal activity and have little or minimal influence on the landscape (PATERSON, 1994). The geomorphological and sedimentological analyses provide conditions to infer that cold-based glaciers could neither erode sufficiently to change the landscape nor transport existing sedimentary material to create the morainic assemblages, eg. HEIN et al. (2016) and SUGDEN et al. (2017).

On the other side, sedimentological characteristics of the moraines cannot confirm the warm-based condition. Considering the sediment texture, sand predominates and fine sediments are quite rare. These textures recorded may be the result of (re)working of preexisting sediments, but without major changes due to absence of continuous meltwater flow. Although thaw is not entirely absent in the area, despite the very low temperatures, it is not efficient enough to modify the sedimentary material. The sublimation of ice beneath the debris cover is also slow, due to extensive bolder cover surface. The modification of morainic material in the study area is most likely to be the result of wind and weathering actions.
Assuming no other changes in regional climate and in the preservation of landforms and sediments at the scale of hundreds of thousands of years (HEIN et al., 2016), changes in these arid environments by slope activity and water flow are limited (HAMBREY and FITZSIMONS, 2010), except at Elephant Head Valley. The current slope activity observed in Elephant Head Valley may be the result of the combination of wind action and solifluction, as observed in other areas in the interior of Antarctica, such as in Patriot Hills (VIEIRA and SIMÕES, 2011; VIEIRA et al., 2012) and in Northern Victory Land (FRENCH and GUGLIELMIN, 1999).

Considering the likely source of supraglacial moraines debris, generally it is assumed that the material is brought to the ice surface by shear bands within the glacier, formed in areas of compressive ice flow (HAMBREY and GLASSER, 2003), as observed in Patriot Hills, approximately $70 \mathrm{~km}$ south of UG area, (FOGWILL et al., 2011; HEIN et al., 2016). Debris brought in surface ice is accumulated as ablation till, when the adjacent ice sublimates. Evidence for such shear bands includes the presence of sediment in subvertical bands in sections through the ice (CASSIDY et al., 1992), and signals of subglacial debris transport, containing fine, sub-rounded and striated clasts (EVANS and O'COFAIGH, 2003). However, these evidences are not present in supraglacial moraines in the study area, with the exception of finer-grained sub-rounded clasts, which may be related to the local processes, such as the constant action of katabatic winds.

The supraglacial moraine observed in Elephant Head blue-ice area (Figs. 5a-b) may be interpreted as a recording of the thinning processes of the ice sheet at UG 
region. The ice thickness change is related to exposition of the steep slopes, which started to contribute with debris to the surrounded areas. The thick debris cover cuts off ablation and creates a protected moraine-covered ice standing above the bare glacier surface (FOGWILL et al., 2011). The morainic slopes observed in Figure $5 \mathrm{~b}$ are likely the result of intense input of debris from the steep slopes to the interior of the valley and to the blue-ice area.

Similar process could be applied to the supraglacial Rossman Cove moraines, where moraines have developed next to the hills. However the sequence of moraine crests and the northeast direction of the tail, argues for influence of the main glacier flow, the UG, on the structure of deposit, represented by the debris accumulation and deformation of the moraine (Figs. 2 and 4). The medial moraine developed at the narrowest section of the UG also reflects the glacier flows, but, in this case, it is inferred that the debris accumulated in downslope areas, as at the base of the slopes, are displaced by the tributary glaciers (Figure 6). Further studies about ice flow in the vicinity of the moraines are necessary to elucidate the process.

In Hein et al. (2016) study, where geomorphic and cosmogenic nuclide data of Patriot and Marble Hills were consistent with an ice sheet that thickened and thinned in response to Quaternary glacial-interglacial cycles, there was no evidence to suggest a change in glaciological conditions that would accompany the loss of the entire ice sheet and the build-up of individual mountain glaciers in this part of Ellsworth Mountains. In addition, in a warming scenario of the interglacial periods of the Quaternary, with the deglaciation of the WAIS, the increased temperature and accumulation would provide favorable conditions for the formation of warm-based glaciers (JAMIESON et al., 2010). Nevertheless, study of Sugden et al. (2017) in the same area shows glacier erosion older than $3.4 \mathrm{Ma}$, and suggests that the landforms indicate the presence of warm-based ice and meltwater, which may be related to mid-Miocene $\sim 14$ million years ago.

The sedimentary and geomorphological characteristics of the morainic deposits suggest a persistent glaciation with effective erosive action on the local relief, but it is inferred that the morainic formation processes correspond to a further deglaciation period. Definitive interpretation of the morainic deposits is still problematic because there are no dating records of the sediments and boulders in the area.
Subsequent analyses of mineralogical provenance of sediments and direction of glacier flow are important to identify the genesis of the material and may say whether or not there was participation of subglacial material. Comparisons can be made with the studies of Hein et al. (2016) and Sugden et al. (2017) in neighbor areas, and with similar studies in other areas in Antarctica.

\section{Conclusions}

Glacial deposits and erosional features preserved in UG ice-free area offer notable inference for the ice fluctuation in this part of Ellsworth Mountains. The geomorphology and sedimentology of the UG area show current erosional and depositional features, which have been created under a thicker overriding ice that covered the area in the past, and in a posterior phase of deglaciation and ice sheet thinning. It is interpreted that the erosional features were shaped by the warm-base conditions, as result of the thicker ice sheet, and the supraglacial moraines are relict features of a latter period of ice thinning in the region. Such features can be used in the reconstruction of ancient surface elevations, extensions of ice and age of the blue-ice areas.

This study leads to initial conclusion that typical indicators of subglacial transport are absent in the area of UG. The large amount of sandy gravel and sand, the low quantity of fine fractions and the absence of striated and faceted clasts indicate distinct agents and processes. The local weathering activity on the slopes and the persistent katabatic winds possibly are the major agents of alteration and transport of the exposed sediments, respectively, which support the existence of the ice sheet for a long period of time.

The geomorphological records point to ancient wet-based thermal conditions reconstructed from a range of landforms, including exposed abrasion marks and glaciotectonic deformation. The latter is represented by lee sides of oversteepening bedrock which follow the ice flow of tributary glaciers, with the stoss part relatively intact whereas the distal part is more impacted by fracturing and quarrying. We infer that the past convergent flow of the thick ice through the valleys has accelerated the ice flow, and has promoted frictional heating and basal activity. The processes of erosion by cold-based ice seem to play a limited role in landscape change in the Union Glacier area. 


\section{Aknowledgments}

The field campaigns were funded by Brazilian National Research Council for Scientific and Technological Development (CNPq) and Brazilian Antarctic Program (PROANTAR). Antarctic Logistics and Expeditions (ALE) provided air transportation and logistic support in the field. Sediment analysis was completed at Fluminense Federal University. Research Support Foundation of the State of Rio de Janeiro (FAPERJ) supported laboratory equipment and students fellowships. ASTER images were offered by Jorge Arigony Neto (Rio Grande Federal University) and processed at Polar and Climate Centre, UFRGS, Brazil. Special thanks to the graduate students Thairiny Fonseca, Livia Aguiar, João Vitor Ramos, Marcos Aurélio Perroni, Matheus Gonçalves and João Pedro Farias Santos for their support in the laboratory. Thanks also to Fábio Magrani for the English language revision.

\section{References}

ACKERT, R. P.; BARCLAY, D. J.; BORNS, H. W.; CALKIN, P. E.; KURZ, M. D.; FASTOOK, J. L.; STEIG, E. J. Measurement of ice sheet elevations in interior West Antarctica. Science, v. 286, p. 276-280, 1999. DOI:10.1126/ science.286.5438.276

ATKINS, C. B.; BARRET, P. J.; HICOCK, S. R. Cold glaciers erode and deposit: evidence from Allan Hills, Antarctica. Geology, v. 7, p. 659-662, 2002.

BARNES, D. K. A.; HILLENBRAND, C. D. Faunal evidence for a late Quaternary trans-Antarctic seaway. Global Change Biology, v. 16, p. 3297-3303, 2010. DOI: 10.1111/j.13652486.2010.02198.x

BENN, D. I.; BALLANTYNE, C. K. Reconstructing the transport history of glaciogenic sediments - a new approach based on the covariance of clast form indices. Sedimentary Geology, v. 91 , p. 215-227, 1994. DOI: 10.1016/0037-0738(94)90130-9

BENNETT, M. R.; HAMBREY, M. J.; HUDDART, D. Modification of clast shape in high-arctic glacial environments. Journal of Sedimentary Research, v. 67, p. 550-559, 1997. DOI: 10.1306/D42685CC-2B26-11D7-8648000102C1865D

BENTley, M. J.; FOGWILl, C. J.; LE BROCQ, A. M.; HUBBARD, A. L.; SUGDEN, D. E.; DUNAI, T. J.; STEWART, P. H. T.; FREEMAN, S. P. H. T. Deglacial history of the West Antarctic Ice Sheet in the Weddell Sea embayment: constraints on past ice volume change. Geology, v. 38, p. 411-
414, 2010. DOI: $10.1130 / G 30754.1$

CASSIDY, W.; HARVEY, R.; SCHUTT, J., DESLISLE, G.; YANAI, K. The meteorite collection sites of Antarctica. Meteoritics, v. 27, p. 490-525, 1992. DOI: 10.1111/j.19455100.1992.tb01073.x

DENTON, G. H.; BOCKEIM, J. G.; RUTFORD, R. H.; ANDERSEN, B. G. Glacial history of the Ellsworth Mountains, West Antarctic, in Webers, G. F., Craddock, C. e Splettstoesser, J. F. (eds), Geology and Paleontology of the Ellsworth Mountains, West Antarctic: Boulder, Colorado, Geological Society of America, Memoir 170, p. 403-432. 1992. DOI: 10.1130/ MEM170-p403

EVANS, J.; O’COFAIGH, C. Supraglacial debris along the front of the Larsen-A Ice Shelf, Antarctic Peninsula. Antarctic Science, v. 15, p. 503-506, 2003. DOI: 10.1017/ S0954102003001615

EVANS, D. J. A.; BENN, D. I. (Eds.). A Practical Guide to the Study of Glacial Sediments. Hodder Education, London, 266 pp, 2004.

FOGWILL, C. J.; HEIN, A. S.; MICHAEL, J.; BENTLEY, M. J.; SUGDEN, D. E. Do blue-ice moraines in the Heritage Range show the West Antarctic ice sheet survived the last interglacial? Palaeogeography, Palaeoclimatology, Palaeoecology, v. 335336, p. 61-70, 2011. DOI:10.1016/j.palaeo.2011.01.027

FOLK, R. L.; WARD, W. C. Petrol Brazos River bar: A study in the significance of grain size parameters. Journal of Sedimentology, v. 3 (27), p. 3-26, 1957. DOI:10.1306/74D706462B21-11D7-8648000102C1865D

FRENCH, H. M.; GUGLIELMIN, M. Observations on the Ice-Marginal, Periglacial Geomorphology of Terra Nova Bay, Northern Victoria Land, Antarctica. Permafrost and Periglacial Processes, v. 10, p. 331-347, 1999. DOI: 10.1002/(SICI)10991530(199910/12)10:4<331:: AID-PPP328>3.0.CO;2-A

HAMBREY, M. J.; GLASSER, N. F. The role of folding and foliation development in the genesis of medial moraines: examples from Svalbard glaciers. Journal of Geology, v. 111, p. 471-485, 2003. DOI: 10.1086/375281

HAMBREY, M. J.; FITZSIMONS, S. J. Development of sediment-landform associations at cold glacier margins, Dry Valleys, Antarctica. Sedimentology, v. 57, p. 857-882, 2010. DOI: $10.1111 /$ j.1365-3091.2009.01123.x

HÄTTERSTRAND, C.; JOHANSEN, N. Supraglacial moraines in Scharffenbergbotnen, Heimefrontfjella, Dronning Maud Land, Antarctica - significance for reconstructing former 
blue ice areas. Antarctica Science, v. 17 (2), p. 225-236, 2005. DOI: $10.1017 / \mathrm{S} 0954102005002634$

HEIN, A.S.; WOODWARD, J.; MARREMO, S. M.; DUNNING, S. A.; STEIG., E. J.; FREEMAN, S. P. H. T.; STUART, F. M.; WINTER, K.; WESTOBY, M. J.; SUGDEN, D. E. Evidence for the stability of the West Antarctic Ice Sheet divide for 1.4 million years. Nature Communications, p. 1-8, 2016. DOI: 10.1038/ncomms 10325

JAMIESON, S. S. R.; SUGDEN, D. E.; HULTON, N. R. J. The evolution of the subglacial landscape of Antarctica. Earth Planetary Science Letters, v. 293, p. 1-27, 2010.

JOUGHIN, I.; SMITH, B. E.; MEDLEY, B. Marine Ice Sheet collapse potentially under way for the Thwaites Glacier Basin, West Antarctica. Science, p. 1-3, 2014. DOI:10.1126/ science. 1249055

LUKAS, S.; BENN, D. I.; BOSTON, C. M.; BROOK, M.; CORAY, S.; EVANS, D. J. A.; GRAF, A.; KELLERERPIRKLBAUER, A.; KIRKBRIDE, M. P.; KRABBENDAM, M.; LOVELL, H.; MACHIEDO, M.; MILLS, S. C.; NYE, K.; REINARDY, B. T. I.; ROSS, F. H.; SIGNER, M. Clast shape analysis and clast transport paths in glacial environments: A critical review of methods and the role of lithology. EarthScience Reviews, v. 121, p. 96-116, 2013. DOI: org/10.1016/j. earscirev.2013.02.005

PATERSON, W. S. B., 1994. The Physics of Glaciers. Pergamon, Oxford, $480 \mathrm{pp}$.

RAISED CONSORTIUM, A community-based geological reconstruction of Antarctic Ice Sheet deglaciation since the Last Glacial Maximum. Quaternary Science Reviews, v. 100, p. 1-9, 2014. DOI:10.1016/j.quascirev.2014.06.025

RIGNOT, E.; MOUGINOT, J.; MORLIGHEM, M.; SEROUSSI, H.; SCHEUCHL, B. Widespread, rapid grounding line retreat of Pine Island, Thwaites, Smith, and Kohler glaciers, West Antarctica, from 1992 to 2011. Geophysical Research Letters, v. 41, p. 3502-3509, 2014.

RIVERA, A.; ZAMORA, R.; RADA, C.; WALTON, J.; PROCTOR, S. Ice dynamics of Union Glacier in the Ellsworth Mountains, West Antarctica. Annals of Glaciology, v. 51 (55), p. 1-6, 2010.

RIVERA, A.; ZAMORA, R.; URIBE, J. A.; JAÑA, R.; OBERREUTER, J. Recent ice dynamic and surface mass balance of Union Glacier in the West Antarctic Ice Sheet. The
Cryosphere, v. 8, p. 1445-1456, 2014. DOI: $10.5194 /$ tc-81445-2014

SCHERER, R. P.; ALDAHAN, A.; TULACZYK, S.; POSSNERT, G.; ENGELHARDT, H.; KAMB, B. Pleistocene collapse of the West Antarctic ice sheet. Science, v. 281, p. 8285, 1998. DOI: 10.1126/science.281.5373.82 Source: PubMed STOREY, B. C. Antarctic. In: Selley, R. C.; Cocks, R. M.; Plimer, I. R. (eds). Encyclopedia of Geology. Elsevier, 2750 p., 2005. DOI:10.1016/B0-12-369396-9/90023-6

STRUGNELL, J. M.; WATTS, P. C.; SMITH, P. J.; ALLCOCK, A. L. Persistent genetic signatures of historic climatic events in an Antarctic octopus. Molecular Ecology, v. 21, p. 2775-2787, 2012. DOI: 10.1111/j.1365-294X.2012.05572.x

SUGDEN, D. E.; BALCO, G.; COWDERY, S. G.; STONE, J. O.; SASS III, L. C. Selective glacial erosion and weathering zones in the coastal mountains of Marie Byrd Land, Antarctica. Geomorphology, v. 67, p. 317-334, 2005. DOI:10.1016/j. geomorph.2004.10.007

SUGDEN, D. E.; BENTLEY, M. J.; Ó COFAIGH, C. Geological and geomorphological insights into Antarctic ice sheet evolution. Philosophical Transactions of the Royal Society, v. 364, p. 1607-1625, 2006. DOI: 10.1098/rsta.2006.1791

SUGDEN, D. E.; HEIN, A. S.; WOODWARD, J.; MARRERO, S. M.; RODÉS, A.; DUNNING, S. A.; STUART, F. M.; FREEMAN, S. P. H. T.; WINTER, K.; WESTOBY, M. J. The million-year evolution of the glacial trimline in the southernmost Ellsworth Mountains, Antarctica. Earth and Planetary Science Letters, v. 469, p. 42-52, 2017. DOI:org/10.1016/j. eps1.2017.04.006

VIEIRA, R.; SIMÕES, J. C. Geomorfologia Glacial dos Montes Patriot e Independence, Montanhas Ellsworth, Manto de gelo da Antártica Ocidental. Revista Brasileira de Geomorfologia, v. 12 , p. $45-58,2011$.

VIEIRA, R.; HINATA, H.; ROSA, K. K.; ZILBERSTEIN, S.; SIMÕES, J. C. Periglacial features in Patriot Hills, Ellsworth Mountains, Antarctica. Geomorphology, v. 155-156, p. 96-101, 2012. DOI: 10.1016/j.geomorph.2011.12.014

WEBERS, G. F.; CRADDOCK, C.; SPLETTSTOESSER, J. F. Geological history of the Ellsworth Mountains, west Antarctica, in: Webers, G. F.; Craddock, C.; Splettstoesser, J. F. Geology and Palaeontology of the Ellsworth Mountains, West Antarctica. Geological Society of America, Memoir 170, 1992. DOI: 10.1130/MEM170-p1 